\title{
Character Education Requirement of Special Batik Works Surakarta
}

\author{
Dyna Prastiwi* \\ Art Education of Graduate School \\ Universitas Negeri Yogyakarta \\ Yogyakarta, Indonesia \\ dynaprastiwi.2018@student.uny.ac.id
}

\author{
Zulfi Hendri \\ Art Education of Graduate School \\ Universitas Negeri Yogyakarta \\ Yogyakarta, Indonesia \\ zulfi_hendri@uny.ac.id
}

\begin{abstract}
Batik is Indonesian cultural inheritance which has become highly valued identity. This research aims to describe the materialization of character education of a Surakarta signature batik. This research was conducted through a qualitative methodology. Surakarta Batik has specific feature both in its stamping and writing processes. The technique and process of making smooth batik requires high motivation and carefulness to develop reliable and patient characters of humans. Surakarta batik motif is variously created with the expectation to bring goodness on the wearers. The meaning in the batik motif has a purpose to develop brilliant and virtuous humans. Generally, it brings values and positive life attitude owned by individuals in influencing behaviors, mindsets, and actions. The data were obtained from an interview with Batik figures and craftsmen in Laweyan Surakarta area in the forms of written documents, books, and photographs of the batik. The findings consisted of the realization of character education in Surakarta signature batik presented in charts and explanations.
\end{abstract}

Keywords - Character Education, Batik, Surakarta

\section{INTRODUCTION}

Indonesia is a multicultural country. It is due to the fact that Indonesia is an archipelago which is rich in cultural diversities. Those diversities cover customs, arts, clothes, and society living patterns. Each culture has unique features. Batik is a high value art work and it has been a part of Indonesian cultures, especially Javanese people since a long time ago. The batik craft is spread almost all over Java area. It causes each region to have specific features and motifs. Solo is an old city in Central Java in the eastern side. Administratively, Solo is actually named Surakarta. The history of batik is dominant in Java island since this island has the high inhabitant density until present days. Due to the density, it is noted in history that Java island has many kingdoms.

According to Sularso (2009:25), India has written about Dwipantara or Hindi Djawa Dwipa Kingdom in Java and Sumatra islands around 200 BC. The historical record of Javanese island asserts it as the center of batik art which has been developing until present days. It has been acknowledged by the world that Batik reached its glory during Mataram I kingdom era until Mataram II kingdom era which was divided into Surakarta and Yogyakarta palaces. The history of batik in Solo cannot be separated from the existence of Surakarta Kasunanan palace and Laweyan village. It was begun from the disunity of Surakarta and Ngayogyakarta palaces as the cause of Giyanti agreement in 1755 .

Surakarta batik typically has flower and bird motifs and designs with beige as primary color with a touch of goldenyellow color. People say that this specific style of Surakarta batik is solo malam in which the batik has bright color on black garment. Batik becomes an inheritance of valuable Javanese culture. Surakarta batik is famous with its traditional patterns and motifs in both its stamping and writing processes. The uniqueness and signature of the motifs and varieties of the batik are full of philosophical values, making it as cultural inheritance to keep and develop (Naomi, 2012:1). On Surakarta batik, it consists of advices and hopes in which are believed to bring goodness and happiness for the wearers. It is all drawn symbolically as the signature features of Surakarta batik (Djoemena, 1990a:10). The batik motif which was only worn by royal family, by the time, could be own and worn by broader society (Kusnanto, 2013:34-55). One of Surakarta batik motifs is battle motif. It is an original Indonesian batik which has been existing since Surakarta palace era. Javanese batik is known to be intricate. It means it has high complexity in term of motifs and colorings. In term of motif, Javanese batik is full of life philosophies. Creativity of batik art does not only deal with local culture but also it deals with the assimilation into foreign culture due to the growth of intercountry trades. Javanese culture which is assimilated into other cultures, such as during trading period with China, India, and Middle East, makes batik has various motifs. According to the styles, batik is grouped into inland and coastal batiks. Meanwhile, based on the cultural influences, according to Doellah (2002), batik could be grouped into palace batik, palace-credited batik, farmer batik, hall batik, India-credited batik, Dutch batik, Chinese batik, Javanese-Hokokai batik, and Indonesian batik. Indonesian batik is as whole techniques, technologies, and motif and cultural developments which are recognized by UNESCO as Masterpiece of Oral and Intangible Heritage of Humanity since October 2, 2009 (Abimanyu Mifzal, 2012:13).

\section{METHODOLOGY}

This research used descriptive qualitative methodology to understand a current phenomenon experienced by the subjects, as for example behaviors, perception, motivation, 
and action holistically (Moleong, 2011:168). The qualitative method is a research procedure to produce spoken and written descriptive data and behaviors which could be experienced by the subjects. The data are a set of important information to be collected and interviewed. The data were obtained from an interview with the batik figures and craftsmen in Laweyan Surakarta area. According to Lofland in Moleong (2011:157), the primary data of qualitative research are words and actions. Words and actions of the observed and interviewed individuals were the main data sources. The primary data source was noted by writing, photographing, observing and interviewing. The data analysis techniques were flow model of analysis. It consists of three components: data reduction, data display, and data conclusion.

\section{FINDINGS}

The batik is Wastra Batik with traditional pattern, in which especially develops and grows Javanese palaces. According to Koentjaraningrat (1990), a nation tribe who always has a specific feature shown by its local culture or other local signatures may take form into daily language usage and its material, activity, or notion cultures. One of the cultures is batik. Then, the features of Surakarta traditional batik are symbolic motifs based on Hindi-Javanese cultures, having sogan, blue, and white colors (Heriyanto Atmojo, 2008:67). Solo batik is famous with its traditional patterns and motifs in both its stamping and writing processes. Its coloring materials come from domestic materials, such as soga. The famous motifs are sidomukti and sidoluhur. The palace, batik, and Klewer market are three identity symbols of Surakarta. One of hereditary traditions which raises the name of the region is batik working or membatik. Surakarta art and batik work make this region as the batik center of Indonesia. Surakarta is known as Batik city, a region to make and trade batiks. As the center of batik, Surakarta has two batik villages as the centers. They are Kauman Batik village and Laweyan Batik village (Naomi, 2012:45). In the development of $13^{\text {th }}$ century, yellow and red colors taken from palu flower were used. Then, in $16^{\text {th }}$ century, the batik works had been spread to not only princesses but also common Javanese people. In around $17^{\text {th }}$ century, soga color as seen below and the realization of Surakarta batik in general were found. In the era of Mataram, Islam citizens were divided into Surakarta Kasunanan (Solo Palace) and Yogyakarta Kasunanan (Yogyakarta Palace). Each kingdom had its own batik styles. The differences between the batiks were disclosed by Djoemena (1990a:21-22) as follow: 1) from the ornament aspect, Solo palace batik has various ornaments which tend to be combination of geometrical-non geometrical ornament variation with smaller size than Yogyakarta palace batik. 2) from the colors of Surakarta batik (Solo Palace batik), brownish-white color (ecru) and brownish-black color were more intense than Yogyakarta. According to Hery Lisbijanto (2013:10-12), there are two batik production methods with each of them having specific characteristics.
Basically, batik production could be divided into two: batik designing and coloring. The first technique, batik designing is done by arranging the motif set and variation. Solo batik (Surakarta) could be divided into two: 1) handdrawn batik produced using canting as the tool to apply hot liquid wax as color barrier on a piece of fabric and 2) stamp batik which is processed using a stamp to replace canting to apply the hot liquid wax as color barrier on the fabric (Yayasan Harapan Kita/BP 3 TMII, 1997:17-20). The second technique, i.e. coloring technique, is done by making color, as done in Central Java, by using dark blue foundation. On the next development, the batik cloth is made in two colors: dark blue and golden soga. Hand-drawn and printed or stamped batik have motif differences including their strengths and weaknesses which differ their techniques in batik designing (Pandono, wawancara Oktober 2019).

Generally, the process to produce batik garment according to Posponegoro (2007:79) could be divided into five stages. First, Nyorek, it is drawing batik pattern on white mori cloth by using a pencil. This process requires skills, creativity, and spontaneity. Second, mbatik or drawing, it is a technique to cover the parts of the white colored ornaments by using batik wax. It requires patience. Third, nembok or caulking, it is covering the white colored ornament using batik wax. It requires determination to finish the drawing seriously. Fourth, nglorod, mbabar, or cleansing, it is a process to remove the wax by soaking the cloth into boiling water continuously by mixing starch and cinder soda. Fifth, njemur or drying, it is a process done on tratag or a tray on kasau-kasau or joist. It requires responsibility in finishing the batik.

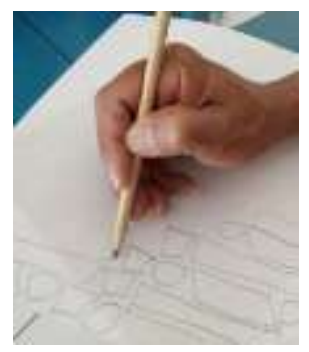

Picture 1. Drawing Pattern

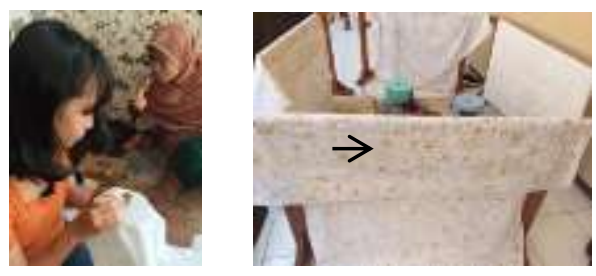

Picture 2. Drawing or Mbatik
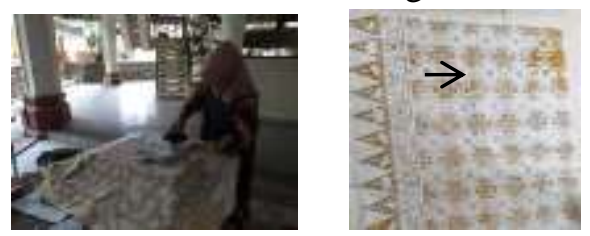
Picture 2. Stamped or Printed Batik

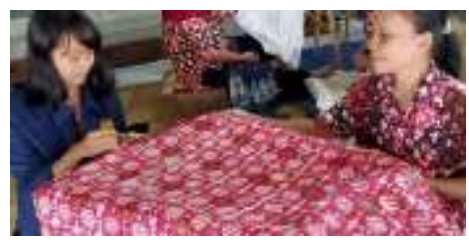

Picture 3. Caulking

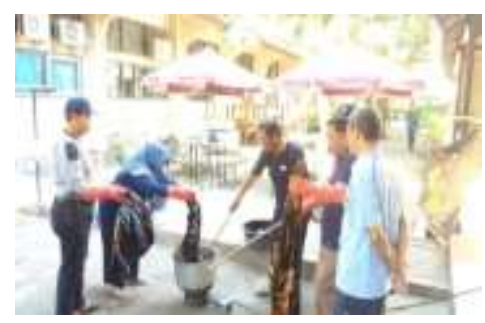

Picture 4. Cleansing

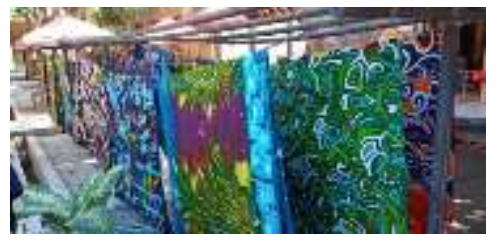

Picture 5. Drying

The character education realization could be defined as character, value, moral, virtue education with the purpose to develop potency as human and citizen with valuable national characters. According to Ki Hajar Dewantara (1977:342-347), education is a process of civilization. It is an effort to share valuable virtues of the ancestors to the next generation; it consists of both maintenance and development of the culture to keep valuable human life. Character education is creating tough and competitive nations, educating children to have morals and to teach children noble morals, be tolerant to other beliefs, be cooperative and helpful to each other, be patriotic, be dynamic, be science and technology-oriented, be faithful and be taqwa to God the Almighty (Kemendiknas, 2011:2). Character is assumed as valuable human behaviors correlated to God the Almighty, personally, to each other, environment, and to nationality which are realized in mind, behavior, feeling, word, and action based on religious norms, laws, manners, cultures, customs, and aesthetics. Indonesia is a famous country in which the people honor manners and kindness, politeness and valuable virtue.

Lickona in his book entitled character education (2013:74) emphasized three important components of good characters: moral knowing, moral feeling, and moral action. To complete the statement, there are 9 character pillars as the reference to this research both in school and outside of school: (a) compassion to Allah and the righteous; (b) responsibility, discipline, and independence; (c) trustful; (d) respectful and polite; (e) full of compassion, caring, and cooperative; (f) confident, creative, and never giving up; $(\mathrm{g})$ being fair and having leadership; (h) kind and being humble, (i) tolerant and loving peace. Through character education, it is expected that adults foster good individuals as expected; individuals whose attitudes are based on positive values and implemented norms in social life.

\section{Examples of Surakarta Signature Batik}

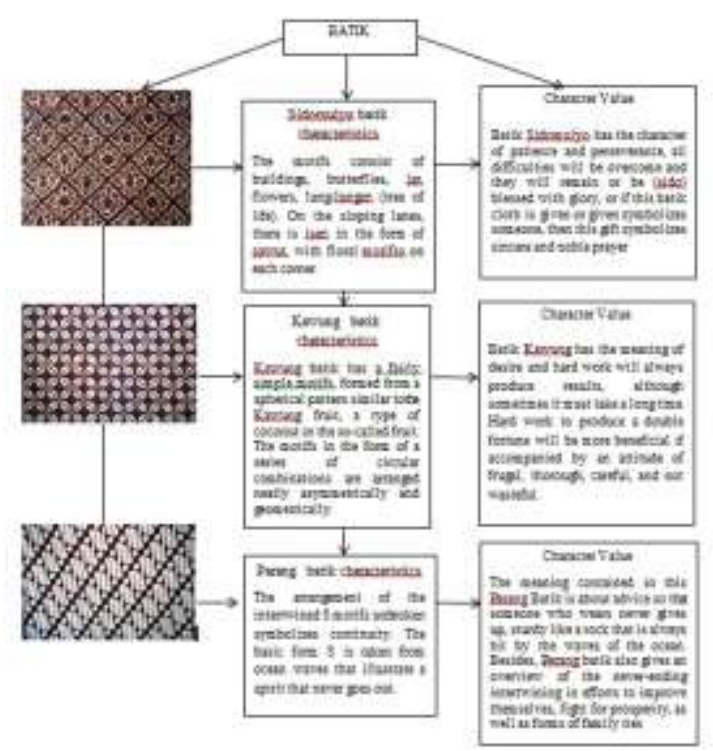

(Figure. Character Values of Batik)

Surakarta (Solo) Batik is not only realization of designing science art which is considered as fine art but also it functions as Javanese fashion worn in relation to life cycle of Javanese, especially in palace environment. The Majesty, Paku Buwana IX, stated that fashion and the ornaments indicated both physical and mental character of the wearers (Pujiyanto, 2010:13). It means that Surakarta batik cloth is not only defined as human fashion but also as something seen as living visions of Javanese people which are full of humanistic or cosmic understandings. Being consistent with the visions, Javanese people tend to have the aforementioned behaviors (Pujiyanto, 2010:11, Herusatoto, 1984:78-81). Drawing batik indirectly teaches character education. Thus, showing character education realization on the activity aspect of drawing is not only seen from formal education but also it is done through the introduction during batik making. The characters are discipline - to learn discipline and to be adhere to regulation in coloring the batik which must be consistent with the already drawn lines with wax or other media. Next, hardworking is an effort to create and finish batik seriously. Creativity is action to create ideas as a production of thought and preference, which is expressed into batik works. Being responsible is an effort to fulfil individuals' responsibilities in daily life in batik making and will always try to finish it well 
although it requires enormous patience or Sabar. It takes endurance to face any obstacle and not to give up. The last is nobility. It covers helping and protecting each other without expecting any reward as the nature of God the Almighty (Pandono, interview on October, 2019).

\section{CONCLUSION}

Batik is a high value art work and it has been a part of Indonesian cultures, especially Javanese people since a long time ago. Batik art is spread almost all over Java island. Surakarta batik typically has flower and bird motifs and designs with beige as primary color touched by golden-yellow color. Surakarta signature batik is solo malam in which the batik has bright color on black cloth. The batik motif which used to be worn only by royal family, as time passed, could be owned and worn by broader society. Surakarta is known as the Batik city, a region to make and trade batiks. As the center of batik, Surakarta has two batik villages as the centers. They are Kauman Batik village and Laweyan Batik village. There are two batik production methods with each of them having specific characteristics.

The research found there are two batik types: the handdrawn batik which is made by creating motif or pattern using a hand or a canting; second, the other one is made by creating patterns and motifs using stamps made off coppers. Several Surakarta signature batiks - the Sidomulya motifs use patient and determined character symbolizing sincere prayer for the wearers. Kawung batik has the meaning of intention and hard efforts to earn fortunes which would be beneficial if it is entailed by efficiency, carefulness, and thriftiness. The character value of Parang is suggestion to make someone wearing the batik not easily give up and stand still as if he was coral or rock hit by oceanic waves. It also describes unbreakable bound of self-improving, prosperity fighting, and family bound. The technique and process of making smooth batik requires high motivation. Thus, it could develop reliable and patient characters of humans. Drawing batik that shows character education realization on the activity of drawing; it is not only seen from formal education but also it is done through introduction during batik making.

Drawing batik is not only defined as human fashion but it is also seen as living ways of Javanese people which are full of humanistic or cosmic understandings. Drawing batik indirectly teaches character education. Among them are to learn discipline and to adhere to regulation.

\section{REFERENCES}

Atmojo, Heriyanto. 2008, Batik Tulis Tradisional Kauman, Solo: Pesona Budaya nan Eksotik, Solo: Tiga Serangkai.

Doellah, Santosa. 2002. Batik, Pengaruh Zaman dan Lingkungan. Solo: Danar Hadi.

Koentjaraningrat (1990). Pengantar Ilmu Antropologi. Jakarta: PT Rineka Cipta

Kusrianto. 2013. Batik Filosofi, Motif \& Kegunaan. Yogyakarta: Penerbit Andi.

Lisbijanto, Herry. 2013. Batik. Yogyakarta: Graha Ilmu.

Lickona, Thomas. Pendidikan Karakter: Panduan Lengkap Mendidik Siswa Menjadi Pintar dan Baik. Bandung: Nusa Media, 2013.

Mifzal, Abimanyu.2012. Mengenal Ragam Batik Nusantara. Yogyakarta: Javalitera.

Moleong, Lexy J, 2011. Metodologi Penelitian Kualitatif. Bandung: PT Remaja Rosdakarya.

Naomi, Kawasaki. Religiositas Tradisi Jawa Islam Dalam Seni Batik. (dalam Jurnal Kebudayaan Islam, Vol.10, No.2, Juli-Desember 2012).

S. Djoemana, Nian. 1990. Ungkapan Sehelai Batik Its Mystery and Meaning. Jakarta: Djembatan.

Sularso, 2009. 60 Tahun Gabungan Koperasi Batik Indonesia. Koperasi Pusat Gabungan Koperasi Batik Indonesia. Jakarta.

INTERVIEWEE

Pardono, 43-Year Old, an Entrepreneur and Batik Artist, address Laweyan, Surakarta. 